\title{
Egg-production dynamics, biochemical composition and hatching success of the subantarctic copepod Paraeuchaeta antarctica: laboratory studies
}

\author{
F. Alonzo ${ }^{1, *}$, P. Mayzaud ${ }^{1}$, S. Razouls ${ }^{2}$ \\ ${ }^{1}$ Observatoire Océanologique, Océanographie Biochimique et Ecologie, LOBEPM, ESA-CNRS 7076, BP 28, \\ 06230 Villefranche-sur-Mer, France \\ ${ }^{2}$ Laboratoire Arago, Observatoire Océanologique, URA-CNRS 117, 66630 Banyuls Cedex, France
}

\begin{abstract}
The reproductive time scale, protein, and lipid contents of eggs and egg hatching success of the predatory calanoid copepod Paraeuchaeta antarctica from the Kerguelen Archipelago was investigated during the winter peak of reproduction, using females in captivity. The mean time taken by females to produce egg sacs was $21.5 \mathrm{~d}$ after the appearance of developing eggs in the oviducts. On average, eggs hatched $23.7 \mathrm{~d}$ after deposition of the sac, at $2^{\circ} \mathrm{C}$. After hatching, females took an average of $9.6 \mathrm{~d}$ to produce a second egg sac. These periods did not vary as a function of collection date (August and September) or time in captivity. Egg mortality within the sac averaged $8 \%$, but strongly increased with increased time in captivity. Captivity also induced a strong decrease in maternal lipid and protein contents and in the number of eggs per sac. However, the lipid content of eggs remained constant and the protein content decreased with increasing brood size. This indicated that $P$. antarctica were limited by available protein rather than lipid. The biochemical composition of the eggs did not change in relation to development, although egg diameter varied from $381 \mu \mathrm{m}$ at egg deposition to $448 \mu \mathrm{m}$ after $15 \mathrm{~d}$ development. Some females were fed with small copepods. Prey clearance and effect of concentration of prey on the female protein content indicated that predatory feeding occurs during winter in $P$. antarctica from Kerguelen. The estimation of the fecundity of $P$. antarctica females led to a production of 175.2 eggs female ${ }^{-1} \mathrm{yr}^{-1}, 91 \%$ of which took place between July and December. From June to October, winter production of eggs relied equally on maternal reserves accumulated during the summer and on carnivorous feeding at low prey concentrations.
\end{abstract}

KEY WORDS: Paraeuchaeta antarctica $\cdot$ Fecundity $\cdot$ Hatching success $\cdot$ Egg biochemical composition · Energy budget

Resale or republication not permitted without written consent of the publisher

\section{INTRODUCTION}

An in situ study on the reproductive biology of the subantarctic copepod Paraeuchaeta antarctica (Giesbrecht, 1902) at Kerguelen Archipelago has illustrated that this species, like its northern counterpart Euchaeta norvegica (Båmstedt 1979), reproduces in winter at a time of low food supply and relies mostly on accumulated lipid reserves to produce eggs (Alonzo et al. 2000, in this issue). This adaptative

${ }^{*}$ E-mail: alonzo@obs-vlfr.fr response, where trophic history plays a key role, frees reproduction from immediate nutritional needs Indeed, maximal lipid content $(50 \%$ of body dry weight) was observed in April at the end of a summer's feeding while the minimum $30 \%$ of body dry weight) was observed in October, after the reproductive season (Alonzo et al. 2000). Therefore, the number of eggs produced over the year should be influenced by the amount of reserves accumulated in females. However, whether winter feeding occurs and helps to support egg production remains to be determined. 
The amount of energy or material invested in reproduction over a season is a key parameter in the energetics of organisms and their predators. Reproductive investment has been investigated for several euphausiid species on the basis of female fecundity, as defined by the total quantity of eggs produced by a female over an entire spawning season (Mauchline 1968). In Euphausia pacifica, a study on its reproductive cycle involved examination of both live individuals and preserved samples (Ross et al. 1982). We found these authors' approach of estimating the number of successive breeding cycles based on spawning frequency and brood interval to be applicable to Paraeuchaeta antarctica also. In euchaetiids, the reproductive time scale has been studied only in Euchaeta norvegica, where females took an average of $22.3 \mathrm{~d}$ to produce an egg sac and the average time taken by the eggs to hatch after egg laying was $18.7 \mathrm{~d}$ (Hopkins 1977). In P. antarctica, the time necessary to complete a breeding cycle, the associated energetic cost, and the seasonal variability are largely unknown. The aim of this study was to determine the contribution of female storage reserves in the winter reproductive budget and to investigate a possible involvement of predatory feeding during the period of limited food availability.

\section{MATERIALS AND METHODS}

Sample collection. Paraeuchaeta antarctica samples were collected in the Bay of Morbihan at IOZ (Interaction-Oiseaux-Zooplancton) Stn 6 (49 $53^{\circ}$ S, 69 96 $96^{\prime}$ E) during winter 1996 at the peak of egg production (July 30 and August 27) using an ORI net (1 mm mesh aperture; $1.6 \mathrm{~m}$ diameter) (Omori 1965). The copepods were obtained by short surface hauls. They were transferred to coolers, maintained at a low concentration in surface seawater, sorted, and returned to the laboratory for experiments.

Egg-production dynamics: laboratory conditions. Females were placed in filtered seawater, and maintained at ambient seawater temperature $\left(2^{\circ} \mathrm{C}\right)$ for eggproduction studies at the densities of 1 female per 250 $\mathrm{ml}$ (either 4 ind. $\mathrm{l}^{-1}$ or 1 ind. per $250 \mathrm{ml}$ jar). Breeding stages were defined as prespawning (with eggs developing in the ovarian diverticules) or egg-bearing, according to Ward \& Robins (1987). Only a few females (10\%) did not produce eggs (see 'Results'). Therefore, females which were neither in prespawning nor in egg-bearing stages were considered as females in the interval between 2 broods. This interval and the corresponding females were named 'interbrood interval' and 'interbrood females', respectively. For each female, the times of egg appearance in the oviducts, egg depo- sition, and egg hatching were noted. To avoid a possible bias related to captivity, the duration of only 2 breeding stages subsequent to capture were calculated for each female. Interbrood females were examined to determine the duration of the prespawning stage (from appearance of eggs in the oviducts to egg deposition) and of the egg-bearing stage (from egg deposition to egg hatching). Prespawning females were used to estimate the duration of the first eggbearing stage and the 'interbrood interval' (from the hatching of nauplii to production of a new egg sac). A fraction of females collected August 27 were simultaneously egg-bearing and prespawning. Those females were studied to determine the interbrood interval and the duration of this second egg-bearing stage.

Female fecundity. The fecundity of females is a function of the number of eggs produced per brood, and of the time interval between broods. Our calculations were based on the egg-production dynamics and on data obtained from preserved samples (Table 1) (Alonzo et al. 2000). Fecundity, $F$, defined as the mean number of eggs produced per adult female over an entire spawning season, was calculated by:

$$
F=\sum_{i} \frac{t_{i} \cdot \bar{n}_{i} \cdot \bar{p}_{i}}{\bar{d}_{i}}
$$

where $t_{i}$ is the duration of the period $i, \bar{p}_{i}$ is the mean proportion of egg-bearing females to total females during $i, \bar{n}_{i}$ is the mean number of eggs per sac during $i$ and $\bar{d}_{i}$ is the mean duration of the egg-bearing stage during $i$.

Table 1. Paraeuchaeta antarctica. Seasonal variations in percentage of egg-bearing females (total adult females) and number of eggs per sac observed in preserved samples collected from the field (Alonzo et al. 2000). Duration: duration of interval between 2 collection dates. Dates presented as $\mathrm{mo} / \mathrm{d} / \mathrm{yr}$

\begin{tabular}{|lcccr|}
\hline \multirow{2}{*}{$\begin{array}{l}\text { Collection } \\
\text { date }\end{array}$} & $\begin{array}{c}\text { Duration } \\
\text { (d) }\end{array}$ & $\begin{array}{c}\text { Percentage } \\
\text { bearing eggs }\end{array}$ & \multicolumn{2}{c|}{ Brood size } \\
\hline $01 / 24 / 96$ & 24 & 6.3 & 28 & 6 \\
$02 / 17 / 96$ & 81 & 7.3 & 34 & 5 \\
$05 / 08 / 96$ & 26 & 0.4 & 36 & 7 \\
$06 / 03 / 96$ & 29 & 4.2 & 42 & 8 \\
$07 / 02 / 96$ & 28 & 5.3 & 46 & 16 \\
$07 / 30 / 96$ & 29 & 12.3 & 61 & 10 \\
$08 / 28 / 96$ & 30 & 70.8 & 69 & 17 \\
$09 / 27 / 96$ & 30 & 41.3 & 55 & 10 \\
$10 / 27 / 96$ & 30 & 42.9 & 53 & 10 \\
$11 / 26 / 96$ & 25 & 23.9 & 51 & 11 \\
$12 / 21 / 96$ & 25 & 51.3 & 41 & 11 \\
$01 / 15 / 97$ & 31 & 18.2 & 32 & 7 \\
$02 / 15 / 97$ & 30 & 2.6 & 35 & 7 \\
$03 / 17 / 97$ & 34 & 5.0 & 31 & 6 \\
$04 / 20 / 97$ & 18 & 3.7 & 34 & 9 \\
& & & & \\
\hline
\end{tabular}


Hatching success. Hatching success was studied with interbrood $(n=26)$ and prespawning $(n=33)$ females from July 30 and with 14 simultaneously eggbearing and prespawning females from August 27 (2 successive broods). Egg-bearing females were observed until hatching. As soon as their eggs hatched, the females were removed and placed in a new $250 \mathrm{ml}$ jar for an interbrood study. The seawater was filtered through a mesh of $200 \mu \mathrm{m}$ mesh aperture. Nauplii and undeveloped eggs were counted and their respective proportions calculated.

Egg and female biochemical content. Groups of 10 egg-bearing females were used for each lipid or protein measurement. Each female and each egg sac were analysed separately. Female prosome lengths, egg diameters and number of eggs per sac were measured. Lipids were extracted (Bligh \& Dyer 1959) and assayed (Barnes \& Blackstock 1973) as described by Alonzo et al. (2000). Proteins were quantified using the BCA reagent kit (Pierce Chemical Company, Rockford, USA). Bovine serum albumin was used as standard.

The lipid and protein contents of eggs are likely to change during the course of embryogenesis. Therefore, measurements were performed on eggs produced synchronously. Furthermore, in order to reveal any possible developmental change, 2 distinct stages of development were considered: (1) 'young egg' samples (YE) were collected from egg-bearing females at the time of egg sac deposition, (2) 'old egg' samples (OE) were collected from egg-bearing females $15 \mathrm{~d}$ after egg sac deposition; in addition (3) 'field' samples (FD) were obtained from egg-bearing females from the wild having different periods of incubation. FD, YE and OE sampling was performed in August and September.

Number of breeding cycles. 'Second brood' samples (SB) were composed of females which were in prespawning condition at time of capture. These females were kept in filtered seawater until completion of the breeding cycle and production of a new egg sac. Those females were collected on Day 1 of the second egg- bearing stage to quantify biochemical contents of eggs and females. SB sampling was performed only in August.

Influence of food. Small zooplankton were collected at Stn IOZ 6 using a WP2 net $(200 \mu \mathrm{m}$ mesh aperture; $0.59 \mathrm{~m}$ diameter). Zooplankton were composed of Drepanopus pectinatus (adult and juvenile stages) and Oithona spp., which were similar in size to Paraeuchaeta antarctica prey (Yen 1991). These small copepods were concentrated and offered as food to $P$. antarctica females. The females used in feeding experiments were at the interbrood stage at the time of capture. Groups of 4 adult females maintained in $1 \mathrm{l}$ received $1 \mathrm{ml}$ ('low concentration of food', 'LO') or $2 \mathrm{ml}$ ('high food concentration', 'HI') of concentrated prey. This procedure was repeated 3 times at $4 \mathrm{~d}$ intervals during the prespawning stage: on each occasion prey were sorted and counted in 3 aliquots of 1 and $2 \mathrm{ml}$. Prey concentrations are given in Table 2. Prey clearance was verified at the end of the experiments. The egg-bearing females were collected on appearance of the egg sac (young eggs). LO and HI individuals were used for estimating egg-production dynamics and assaying biochemical contents of eggs and females.

Data analysis. The F-test (Sokal \& Rohlf 1981) was used to test the significance of the various linear relationships (regression). An $F$ test (ANOVA) or nonparametric, Kruskall-Wallis $H$ - and Mann-Whitney $U$-tests (Sokal \& Rohlf 1981) were used to test differences between samples (assume no difference as the null hypothesis). In all the cases, the alpha level was 0.05 .

\section{RESULTS}

\section{Egg-production dynamics and fecundity}

In all experiments, mortality of Paraeuchaeta antarctica was low $\left(\leq 0.8 \%\right.$ of total ind. $\left.\mathrm{d}^{-1}\right)$ and remained so throughout the $86 \mathrm{~d}$ experimental period.

Table 2. Quantity and specific composition of prey additions $\left(1^{-1}\right)$ estimated from 3 aliquots. LO: lower food; HI: higher food

\begin{tabular}{|c|c|c|c|c|c|c|}
\hline \multirow{2}{*}{$\begin{array}{l}\text { Vol. of prey } \\
\text { supplied }\end{array}$} & \multirow[b]{2}{*}{ Adult females } & \multicolumn{2}{|c|}{ Drepanopus pectinatus } & \multirow{2}{*}{$\overline{\mathrm{C} 3}$} & \multirow{2}{*}{$\begin{array}{l}\text { Oithona } \\
\text { spp. }\end{array}$} & \multirow{2}{*}{$\begin{array}{l}\text { Total } \\
\text { prey }\end{array}$} \\
\hline & & C5 & $\mathrm{C} 4$ & & & \\
\hline \multicolumn{7}{|l|}{$\mathrm{LO}(1 \mathrm{ml})$} \\
\hline 1 & $1 \pm 1$ & $1 \pm 1$ & $3 \pm 2$ & $30 \pm 1$ & $4 \pm 2$ & $38 \pm 1$ \\
\hline 2 & $1 \pm 1$ & $3 \pm 1$ & $4 \pm 1$ & $12 \pm 2$ & $5 \pm 1$ & $25 \pm 1$ \\
\hline 3 & 0 & $3 \pm 1$ & $5 \pm 1$ & $25 \pm 5$ & $25 \pm 5$ & $58 \pm 2$ \\
\hline \multicolumn{7}{|l|}{ HI (2 ml) } \\
\hline 1 & $1 \pm 1$ & $1 \pm 1$ & $6 \pm 2$ & $60 \pm 2$ & $10 \pm 1$ & $78 \pm 3$ \\
\hline 2 & $1 \pm 1$ & $6 \pm 1$ & $8 \pm 1$ & $23 \pm 2$ & $12 \pm 1$ & $50 \pm 1$ \\
\hline 3 & $1 \pm 1$ & $7 \pm 1$ & $10 \pm 1$ & $50 \pm 11$ & $51 \pm 8$ & $119 \pm 2$ \\
\hline
\end{tabular}


Most females produced eggs $(89.3 \%$ of all individuals investigated). Those few females which did not produce eggs remained at the interbrood stage at all times. A complete regression of developing eggs in the oviducts was observed in $4 \%$ of the females in the prespawning stage $(\mathrm{n}=226)$. This process could be observed in both starved and fed copepods with equal frequency. During the egg-bearing stage, a fraction of females lost their egg sac. A new breeding cycle was initiated immediately in almost $10 \%$ of the cases. Sac loss happened at different frequencies, related to the breeding stage of females at the time of capture: $47 \%$ of egg sacs were lost when females were at the interbrood stage; $19 \%$ of egg sacs were lost when females were prespawning. When the egg-bearing stage was successful (i.e. no regression or sac loss), a second breeding cycle was induced immediately for $19 \%$ of the females which were interbrood at the time of capture and for all females which were prespawning at the time of capture.

The mean duration of each breeding stage is reported in Table 3. No significant difference could be detected in duration of the egg-bearing stage in relation to sampling date or breeding stage at the time of capture $(\mathrm{n}=73, \mathrm{p}=0.57)$. Similarly, the interbrood interval recorded for prespawning/egg-bearing females was comparable between the July and August samples, with no significant difference $(\mathrm{n}=47, \mathrm{p}=$ 0.852). In both cases, it was shorter than the duration of the prespawning stage. Appearance of a new brood in the ovarian diverticula occurred while females were still bearing egg sacs. No effect could be seen of feeding and starvation conditions on the duration of prespawning $(\mathrm{n}=26, \mathrm{p}=0.279)$ and egg-bearing stages (n $=59, \mathrm{p}=0.255)$.

Because the duration of the egg-bearing stage was measured only in August and September, we assumed that it remained constant over the year. Using this assumption we calculated fecundity, $F=175.2$ eggs female ${ }^{-1} \mathrm{yr}^{-1}$.

\section{Brood size}

The number of eggs per sac is shown in Table 4. In YE and OE samples, originating from ready-to-spawn females incubated over short periods of time, the numbers of eggs per sac were not different from those observed in FD samples ( $\mathrm{n}=116, \mathrm{p}=0.587$ ). Similarly, no significant difference in numbers of eggs per sac could be detected among females incubated over longer periods of captivity (i.e. SB, LO and $\mathrm{HI}$; $\mathrm{n}=61$, $p=0.143)$. In these latter samples, individuals showed a lower brood size than observed in FD, YE and OE samples ( $\mathrm{n}=177, \mathrm{p}<0.001)$, suggesting a strong influence of duration of captivity.

\section{Hatching success}

Four categories of hatching success were defined in relation to the proportion of eggs hatching in ovisacs: 0,1 to 50,50 to 75 and 75 to $100 \%$. The proportions calculated in each category are reported in Fig. 1. A strong influence of breeding stage at the time of capture could be observed. The greatest hatching success was recorded with the first brood of prespawning eggbearing females: $86 \%$ of their ovisacs yielded 75 to $100 \%$ hatching eggs. This proportion decreased to $64 \%$ in the second brood. Similarly, in prespawning females, $61 \%$ of ovisacs yielded 75 to $100 \%$ hatched eggs; $25 \%$ of these females produced no hatching eggs $(0 \%)$. For interbrood females at the time of capture, $57 \%$ had $0 \%$ hatching egg sacs, while $30 \%$ of ovisacs produced 75 to $100 \%$ hatching eggs.

\section{Egg and female sizes}

Prosome length and egg diameter are given in Table 4. No significant difference could be detected in prosome length $(\mathrm{n}=167, \mathrm{p}=0.145)$. Thus, female size was independent of collection date and food level.

Table 3. Paraeuchaeta antarctica. Durations of the various breeding stages of adult females. Prespawn: prespawning; egg-bear.: egg-bearing. Dates presented as $\mathrm{mo} / \mathrm{d} / \mathrm{yr}$

\begin{tabular}{|c|c|c|c|c|c|c|}
\hline \multirow{2}{*}{$\begin{array}{l}\text { Date of } \\
\text { capture }\end{array}$} & \multirow{2}{*}{$\begin{array}{l}\text { Breeding stage } \\
\text { at time of capture }\end{array}$} & \multirow[t]{2}{*}{ Stage } & \multicolumn{4}{|c|}{ - Duration $(\mathrm{d})$} \\
\hline & & & Mean & $\mathrm{SD}$ & Min. & Max. \\
\hline 07/30/96 & Interbrood & Prespawning & 21.5 & 7.0 & 8 & 33 \\
\hline- & $(\mathrm{n}=26)$ & Egg-bearing & 22.5 & 4.7 & 10 & 31 \\
\hline- & Prespawning & Egg-bearing & 23.5 & 3.4 & 15 & 33 \\
\hline- & $(\mathrm{n}=33)$ & Interbrood interval & 9.5 & 5.5 & 3 & 27 \\
\hline 08/27/96 & Prespawn./egg-bear. & Interbrood interval & 9.9 & 7.6 & 3 & 33 \\
\hline- & $(\mathrm{n}=14)$ & 2nd egg-bearing & 25.2 & 4.8 & 18 & 34 \\
\hline
\end{tabular}


Table 4. Paraeuchaeta antarctica. Female prosome length, egg diameter and brood size in the various samples (10 females and 10 egg sacs were used for each measurement). Dates presented as mo/d/yr

\begin{tabular}{|c|c|c|c|c|c|c|c|}
\hline \multirow{2}{*}{$\begin{array}{l}\text { Date of } \\
\text { capture }\end{array}$} & \multirow[t]{2}{*}{ Sample } & \multicolumn{2}{|c|}{ Prosome length (mm) } & \multicolumn{2}{|c|}{ Egg diameter $(\mu \mathrm{m})$} & \multicolumn{2}{|c|}{ Eggs per sac } \\
\hline & & $\bar{X}$ & $\mathrm{SD}$ & $\bar{X}$ & $\mathrm{SD}$ & $\bar{x}$ & SD \\
\hline 07/30/96 & Field & 6.10 & 0.23 & 414 & 45 & 60 & 11 \\
\hline 08/27/96 & Field & 6.18 & 0.18 & 410 & 32 & 53 & 18 \\
\hline 07/30/96 & Young egg & 6.38 & 0.23 & 393 & 11 & 55 & 17 \\
\hline 08/27/96 & Young egg & 6.15 & 0.21 & 374 & 20 & 60 & 14 \\
\hline 07/30/96 & Old egg & 6.19 & 0.22 & 398 & 20 & 59 & 14 \\
\hline 08/27/96 & Old egg & 6.27 & 0.11 & 488 & 35 & 54 & 12 \\
\hline 07/30/96 & 2nd brood & 6.26 & 0.23 & 384 & 12 & 36 & 10 \\
\hline 07/30/96 & Low food & 6.16 & 0.26 & 387 & 17 & 31 & 12 \\
\hline 07/30/96 & High food & 6.17 & 0.19 & 399 & 19 & 39 & 17 \\
\hline
\end{tabular}

A possible seasonal change in egg diameter was investigated. Egg diameters from FD, YE and OE samples were pooled and compared in relation to collection date. No significant difference was detected $(\mathrm{n}=$ $116, \mathrm{p}=0.279$ ). A developmental influence was shown by comparing FD, YE and OE samples independent of collection date $(\mathrm{n}=116, \mathrm{p}<0.001)$. Young eggs were smaller $(381 \mu \mathrm{m})$ than old eggs from the end of the egg-bearing stage $(448 \mu \mathrm{m})$. FD samples were composed of eggs at various development times and showed an intermediate mean value $(411 \mu \mathrm{m})$. The shape and color of eggs also changed during development: young eggs were brown, opaque and spherical, while older eggs were translucent with large orange oil globules and appeared more elongated along the anterior-posterior axis.

Egg sizes at Day 1 of egg release from YE, SB, LO and $\mathrm{HI}$ samples were compared to examine the possible influence of food level and number of breeding cycles. Egg sizes were not different among samples YE, SB and LO $(n=81, p=0.757)$. ANOVA detected a significant difference between sample $\mathrm{HI}$ and the others $(n=101, p=0.011)$. Thus, food offered at a high level led to eggs of a slightly larger size while other treatments led to eggs comparable to those from the field.

\section{Female biochemical composition}

The lipid and protein contents of females are shown in Tables 5 \& 6, respectively. Female lipid content varied significantly between samples $(\mathrm{n}=80, \mathrm{p}<0.001)$. Three groups within which female lipid content did not differ could be discriminated: FD samples $(\mathrm{n}=16$, $p=0.386$ ) with high lipid content; YE and OE samples $(\mathrm{n}=38, \mathrm{p}=0.217$ ) with medium lipid content and, $\mathrm{SB}$, LO and HI samples $(n=26, p=0.252)$ with low lipid content.
In FD samples, female protein contents differed between collection dates $(n=20, p<0.001)$. In starved females collected at the end of July, captivity introduced a progressive decline in protein concentration ( $\mathrm{n}=40, \mathrm{p}<0.001$ for FD, YE and OE and SB samples). In fed copepods, protein per female was significantly higher at a high food level than at a low food level $(\mathrm{n}=$ $20, p=0.023)$. A similar decrease related to captivity could be seen in protein content of copepods collected in August ( $\mathrm{n}=30, \mathrm{p}=0.005)$.

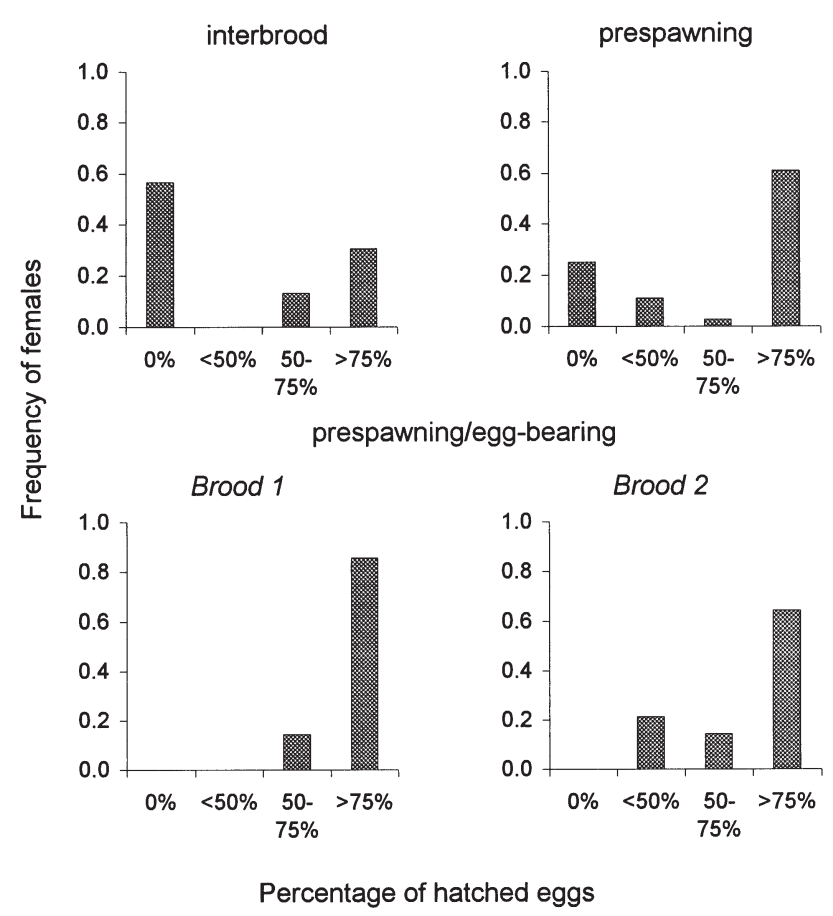

Fig. 1. Paraeuchaeta antarctica. Frequency distribution of females in relation to hatching success (proportion of hatched eggs) and breeding stage at time of capture. Brood 1 and Brood 2 = the 2 successive breeding cycles of prespawning/egg-bearing females examined for hatching 
Table 5. Paraeuchaeta antarctica. Lipid content $(\mu \mathrm{g})$ of females and eggs in the various samples (10 females and 10 egg sacs were used for each measurement). Dates presented as $\mathrm{mo} / \mathrm{d} / \mathrm{yr}$

\begin{tabular}{|c|c|c|c|c|c|c|c|}
\hline \multirow{2}{*}{$\begin{array}{l}\text { Date of } \\
\text { capture }\end{array}$} & \multirow[t]{2}{*}{ Sample } & \multicolumn{2}{|c|}{ Female } & \multicolumn{2}{|c|}{ Egg } & \multicolumn{2}{|c|}{ Egg sac } \\
\hline & & $\bar{x}$ & $\mathrm{SD}$ & $\bar{X}$ & SD & $\bar{x}$ & $\mathrm{SD}$ \\
\hline 07/30/96 & Field & 2235 & 785 & 5.8 & 0.7 & 372 & 87 \\
\hline 08/27/96 & Field & 1810 & 406 & 5.9 & 0.4 & 252 & 106 \\
\hline 07/30/96 & Young eggs & 1690 & 479 & 6.9 & 1.5 & 339 & 124 \\
\hline 08/27/96 & Young eggs & 1489 & 412 & 5.9 & 1.0 & 343 & 81 \\
\hline 07/30/96 & Old eggs & 1486 & 380 & 6.2 & 1.5 & 353 & 78 \\
\hline 08/27/96 & Old eggs & 1246 & 293 & 6.7 & 0.6 & 353 & 86 \\
\hline 07/30/96 & Second brood & 881 & 376 & 5.8 & 0.6 & 174 & 44 \\
\hline 07/30/96 & Low food & 646 & 600 & 7.0 & 2.6 & 204 & 55 \\
\hline 07/30/96 & High food & 937 & 556 & 6.9 & 1.9 & 231 & 80 \\
\hline
\end{tabular}

Table 6. Paraeuchaeta antarctica. Protein content $(\mu \mathrm{g})$ of females and eggs in the various samples (10 females and 10 egg sacs were used for each measurement). Dates presented as mo/d/yr

\begin{tabular}{|c|c|c|c|c|c|c|c|}
\hline \multirow{2}{*}{$\begin{array}{l}\text { Date of } \\
\text { capture }\end{array}$} & \multirow{2}{*}{ Sample } & \multicolumn{2}{|c|}{ Female } & \multicolumn{2}{|c|}{ Egg } & \multicolumn{2}{|c|}{ Egg sac } \\
\hline & & Mean & $\mathrm{SD}$ & Mean & $\mathrm{SD}$ & Mean & $\mathrm{SD}$ \\
\hline 07/30/96 & Field & 2100 & 298 & 5.3 & 0.4 & 299 & 52 \\
\hline 08/27/96 & Field & 1242 & 159 & 5.3 & 0.4 & 334 & 45 \\
\hline 07/30/96 & Young eggs & 1597 & 261 & 5.2 & 0.8 & 296 & 44 \\
\hline $08 / 27 / 96$ & Young eggs & 1248 & 168 & 4.9 & 0.7 & 295 & 49 \\
\hline 07/30/96 & Old eggs & 1472 & 206 & 4.6 & 0.4 & 278 & 85 \\
\hline $08 / 27 / 96$ & Old eggs & 958 & 211 & 4.8 & 0.7 & 273 & 88 \\
\hline 07/30/96 & Second brood & 1029 & 175 & 6.6 & 1.5 & 274 & 58 \\
\hline 07/30/96 & Low food & 851 & 256 & 6.4 & 1.8 & 182 & 74 \\
\hline $07 / 30 / 96$ & High food & 1117 & 245 & 7.1 & 1.2 & 292 & 100 \\
\hline
\end{tabular}

A linear relationship could be determined between mean lipid and protein contents (mg per female): lipid $=1.14$, protein $-0.09 ; n=9, \mathrm{R}^{2}=0.724 ; \mathrm{p}=0.002$.

\section{Egg biochemical composition}

The lipid and protein content of the eggs are given in Tables 5 \& 6, respectively. No significant difference was observed in the concentrations of lipid per egg between samples $(n=88, p=0.085)$. Egg lipid content remained constant between collection dates, development time of the eggs, first and second broods and food levels offered to the female.

The amount of protein per egg recorded in YE and OE samples was not different from that observed in FD samples ( $\mathrm{n}=57, \mathrm{p}=0.056)$. Similarly, SB, LO and HI samples showed equal egg protein contents $(\mathrm{n}=30, \mathrm{p}=$ 0.556), independent of food level or number of breeding cycles. Protein content of eggs in these latter samples were higher than those in FD, YE and OE samples (n = 87, p < 0.001).

\section{Relation between egg biochemical content, brood size and female dry weight}

In our samples, the dry weight of females was estimated assuming that the sum of lipid and protein contents accounts for $90 \%$ of the total dry weight (Alonzo et al. 2000). Neither the lipid nor protein content of the eggs showed a significant relationship with female dry weight ( $p>0.05$ in both cases). However, the protein content of the eggs was related to the number of eggs per sac, with a lower protein content per egg in large broods $(n=9, R=0.753, p=0.001)$.

\section{DISCUSSION}

\section{Breeding cycle}

In the present study, we found that $4 \%$ of female Paraeuchaeta antarctica resorbed their eggs within the oviducts during the prespawning stage and produced no sacs. A similar process was observed in 
Euchaeta norvegica (Hopkins 1977). Moreover, some of the egg-bearing females lost their egg sacs during the egg-bearing stage. The high difference in frequency of egg-sac loss reported between initially prespawning and initially interbrood females showed that egg sacs produced after Day 30 of captivity were more fragile than those produced earlier. Such an influence of captivity supports the idea of an experimental artefact.

During the Paraeuchaeta antarctica breeding cycle, a succession of interbrood to prespawning to egg-bearing were not always observed. In late August, interbrood stages were absent, because females had started to develop a second brood prior to releasing their nauplii. The duration of the prespawning stage found in the present study was similar to that described in Euchaeta norvegica (22.3 d: Hopkins 1977), and the average time taken for the eggs to hatch was longer than that observed at $10^{\circ} \mathrm{C}$ in E. norvegica (18.7 d). Similarly, the egg hatching time of $P$. antarctica was much longer than those recorded at $15^{\circ} \mathrm{C}$ in other species of egg-carrying calanoids (Kiørboe \& Sabatini 1995). The difference might be explained by the influence of temperature on copepod growth rates (Huntley \& Lopez 1992). Such a long hatching time could enhance the reproductive risk associated with the mortality of egg-bearing females, unless one hypothesizes that predation rate of ovigerous females is lower in $P$. antarctica than in other species. Reproduction in winter, when large predators such as seabirds are not present (Weimerskirch et al. 1989, Bocher 1997) could minimize this risk.

\section{Female fecundity}

Our estimation of fecundity concerned a theoretical female which would survive the whole year and thus did not take into consideration the real longevity of females. This approximation should not be of consequence, as $91 \%$ of the fecundity was concentrated in the period of July to December. The low value that we obtained, compared to species that release their eggs into the water column, is consistent with the fecundity of species that carry their eggs in a sac (Mauchline 1998).

\section{Hatching success}

In our samples, we interpreted changes in hatching success as a result of the experimental conditions. Mean hatching and egg survival rates were similar to those recorded by Hopkins (1977) for Euchaeta norvegica, and can be considered as similar to naturally occurring rates. Indeed, hatching success decreased progressively with increasing duration of captivity. As our females were kept individually, without the presence of adult males, we attribute such lower hatching rate to lack of fertilization. This is consistent with the short time of spermatophore attachment on the female and the necessity for remating in the Kerguelen population (Alonzo et al. 2000).

\section{Egg size}

In our samples, egg size varied from 381 to $448 \mu \mathrm{m}$ in relation to embryonic development. Elongation of eggs along the anterior-posterior axis during development was reported in Euchaeta norvegica by Hopkins (1977), with diameter increasing from 351 to $507 \mu \mathrm{m}$, but no variation in egg size was observed in relation to female body weight by Nemoto et al. (1976). In the present study, no seasonal trend was recorded in egg size of $P$. antarctica from Kerguelen (Alonzo et al. 2000). However, we detected a greater egg size in females at the high food level than at other food levels. This increase cannot be clearly interpreted, and might be associated with the high protein content of these eggs.

\section{Brood size and maternal reserves}

In winter, egg production is recognized to rely essentially on body reserves in Paraeuchaeta antarctica (Littepage 1964, Alonzo et al. 2000) and in Euchaeta norvegica (Båmstedt 1979). A seasonal decrease in female dry weight has been shown to be concomitant with the major peak of egg production. Our experimental results strongly suggested that the number of eggs per sac was related to female dry weight. We observed that both lipid and protein contents of the brood decreased with decreasing female dry weight. This observation could lead to the inference that egg production is limited by both nitrogen and carbon reserves. However, the lipid content of eggs was constant whereas protein per egg decreased with increasing brood size. We conclude that in $P$. antarctica the limiting factor seems to be protein rather than lipid content.

\section{Winter predation}

In this study, the prey clearance observed in the LO and $\mathrm{HI}$ jars showed that predatory feeding activity by Paraeuchaeta antarctica occurred in winter. Yen (1991) did not detect feeding activity in $P$. antarctica from Crocker Passage during winter, although her experi- 
Table 7. Paraeuchaeta antarctica. Energy budget of adult females during winter. Energy equivalents are calculated for the consumption of maternal reserves and for reproduction from June to October. Reproduction corresponds to the production of 136 eggs. Energy equivalents of lipids and proteins from Winberg (1971)

\begin{tabular}{|c|c|c|c|c|c|}
\hline \multirow[t]{2}{*}{ Component } & \multirow{2}{*}{$\begin{array}{l}\text { Energy equiv. } \\
\left(\mathrm{J} \mathrm{mg}^{-1}\right)\end{array}$} & \multicolumn{2}{|c|}{ Loss of maternal reserves } & \multicolumn{2}{|c|}{ Reproduction } \\
\hline & & Mass (mg) & Energy (J) & Mass (mg) & Energy $(\mathrm{J})$ \\
\hline Lipid & 39.5 & 2.20 & 86.9 & 1.25 & 49.4 \\
\hline Protein & 23.6 & 1.55 & 36.6 & 1.12 & 26.4 \\
\hline Total & & 3.75 & 123.5 & 2.37 & 75.8 \\
\hline
\end{tabular}

ments were conducted at similar prey concentrations ( 25 to 50 prey $\mathrm{l}^{-1}$ ). This difference between Kerguelen and Crocker Passage could be interpreted as a response to a lower food availability in winter in the antarctic waters than in the subantarctic zone.

The difference in protein content of females in relation to food level showed that the availability of food could influence the organic content of females. Thus, our observation of a greater decrease in organic content between August and September in individuals maintained in filtered seawater $\left(2.43 \mathrm{mg}_{\text {copepod }}{ }^{-1}\right)$ than in individuals collected in situ $(1.28 \mathrm{mg}$ copepod $^{-1}$ ) strongly suggests the occurrence of predatory feeding in Paraeuchaeta antarctica in the field. No general decrease in feeding by $P$. antarctica was observed during winter in the waters around South Georgia (Øresland \& Ward 1993). Båmstedt (1979) suggested that the abundance of prey organisms is the most important environmental factor governing the energetic budget of reproduction in Euchaeta norvegica. Considering the size range of prey ingested by P. antarctica (Yen 1991), the available potential prey concentration in the water column in the Kerguelen area was approximately 2 prey $\mathrm{l}^{-1}$ during the winter period (Program IOZ unpubl. data). The question of whether predatory feeding might support reproduction at this prey concentration requires direct investigation of the reproductive energy budget.

\section{Energy budget}

Energy reserves of females are used in winter for egg production and body maintenance. In winter, body dry-weight loss of adult females took place from June to October, over a period of $146 \mathrm{~d}$ (Alonzo et al. 2000). Over the same period, a total of 136 eggs was produced per female. The corresponding energy equivalent is shown in Table 7. Erhiff (1998) reported in Paraeuchaeta antarctica a respiration rate of $62 \mu \mathrm{l}$ $\mathrm{O}_{2}$ adult female ${ }^{-1} \mathrm{~d}^{-1}$. Considering the energy loss as $19.38 \mathrm{~J}$ per $\mathrm{ml} \mathrm{O}_{2}$ (Båmstedt 1979), the total respiration loss was $175 \mathrm{~J}$. Therefore, reproduction ac- counted for $30 \%$ of the total energy requirement of $250 \mathrm{~J}$. Even though our calculations do not include excretion loss, the energy provided by maternal reserves was not sufficient to meet the requirement of reproduction and respiration. This means that at least $50 \%$ of the energy requirements were provided by predatory feeding. This situation contrasts with the results from a more herbivorous/omnivorous subantarctic copepod, Neocalanus tonsus, in which winter feeding was not necessary (Ohman 1987). In this species, $25 \%$ of the daily consumption of lipids was invested in the production of eggs. In the arctic, the copepods Calanus glacialis and C. hyperboreus similarly relied on stored energy to reproduce in winter. The mean reproductive investment accounted respectively for 77 and $63 \%$ of the daily carbon requirements (Smith 1990, Hirche \& Kattner 1993). These greater values reflected markedly different reproductive strategies.

\section{Conclusion}

In the Kerguelen Archipelago, reproduction of Paraeuchaeta antarctica during winter, when feeding conditions are unfavorable, relies on maternal lipid storage accumulated during summer and on carnivorous feeding at low prey concentration. This species produces a low number of eggs with large lipid and protein contents. The broods are carried attached to the mother for $24 \mathrm{~d}$, involving a high degree of maternal care that results in a high hatching rate. The presence of internal food stores is essential for the survival of naupliar stages until food conditions are favorable.

Acknowledgements. We would like to thank Dr M. Ohman and Dr E. Rochelle-Newall for commenting on and editing the manuscript and Mr Gildas Roudaut for technical assistance. Financial support was provided by IFRTP as part of the IOZ programme. Our thanks also go to the captains and crews of the RV 'La Curieuse' for their assistance during sampling. The authors are grateful to anonymous referees for their helpful comments on this manuscript. 


\section{LITERATURE CITED}

Alonzo F, Mayzaud P, Razouls S (2000) Egg production, population structure and biochemical composition of the subantarctic copepod Paraeuchaeta antarctica in the Kerguelen Archipelago. Mar Ecol Prog Ser 205:207-217

Båmstedt U (1979) Reproductive bioenergetics within the summer and winter generations of Euchaeta norvegica (Copepoda). Mar Biol 54:135-142

Barnes H, Blackstock J (1973) Estimation of lipids in marine animals and tissues: detailed investigation of the sulfovanillin method for total lipids. J Exp Mar Biol Ecol 12:103-118

Bligh EG, Dyer WJ (1959) A rapid method of total lipid extraction and purification. Can J Biochem Physiol 37: 911-917

Bocher P (1997) Stratégies de recherche alimentaire comparées chez trois espèces d'oiseaux plongeurs planctonophages. DEA de Biologie du Comportement, Université Paris XIII, Villetaneuse

Erhiff A (1998) Composition et structure du zooplancton du secteur indien de l'Océan Austral. Rôle du métabolisme respiratoire. Thèse de doctorat de l'Université d'AixMarseille III, Marseille

Hirche HJ, Kattner G (1993) Egg production and lipid content of Calanus glacialis in spring: indication of a food-dependent and food-independent reproductive mode. Mar Biol 117:615-622

Hopkins CCE (1977) The relationship between maternal body size and clutch size, development time and egg mortality in Euchaeta norvegica (Copepoda: Calanoida) from Loch Etive, Scotland. J Mar Biol Assoc UK 57:723-733

Huntley ME, Lopez MDG (1992) Temperature-dependent production of marine copepods: a global synthesis. Am Nat 140:201-242

Kiørboe T, Sabatini M (1995) Scaling of fecundity, growth and development in marine planktonic copepods. Mar Ecol Prog Ser 120:285-298

Littlepage JL (1964) Seasonal variations in lipid content of two

Editorial responsibility: Otto Kinne (Editor),

Oldendorf/Luhe, Germany
Antarctic marine Crustacea. In: Carrick R (ed) Biologie antarctique. Hermann, Paris, p 463-470

Mauchline J (1968) The development of the eggs in the ovaries of euphausiids and estimates of fecundity. Crustaceana 14:155-163

Mauchline J (1998) The biology of calanoid copepods. In: Baxter JHS, Southward AJ, Tyler PA (eds) Advances in marine biology. No. 33. Academic Press, San Diego

Nemoto T, Mauchline J, Kamada K (1976) Brood size and chemical composition of Pareuchaeta norvegica (Crustacea: Copepoda) in Loch Etive, Scotland. Mar Biol 36:151-157

Ohman MD (1987) Energy sources for recruitment of subantarctic copepod Neocalanus tonsus. Limnol Oceanogr 32:1317-1330

Omori M (1965) A 160-cm opening-closing plankton net. I. Description of the gear. J Oceanogr Soc Jpn 21:212-220

Øresland V, Ward P (1993) Summer and winter diet of four carnivorous copepod species around South Georgia. Mar Ecol Prog Ser 98:73-78

Ross RM, Daly KL, English TS (1982) Reproductive cycle and fecundity of Euphausia pacifica in Puget Sound, Washington. Limnol Oceanogr 27:304-314

Smith SL (1990) Egg production and feeding prior to the spring bloom of phytoplankton in Fram Strait, Greenland Sea. Mar Biol 106:59-69

Sokal RR, Rohlf FJ (1981) Biometry. The principles and practice of statistics in biological research, 2nd edn. WH Freeman \& Co, New York

Ward P, Robins DB (1987) The reproductive biology of Euchaeta antarctica Giesbrecht (Copepoda: Calanoida) at South Georgia. J Exp Mar Biol Ecol 108:127-145

Weimerskirch H, Zotier R, Jouventin P (1989) The avifauna of the Kerguelen Islands. Emu 89:15-29

Winberg GG (1971) Methods for the estimation of production of aquatic animals. Academic Press, London

Yen J (1991) Predatory feefing behaviour of an Antarctic marine copepod, Euchaeta antarctica. Polar Res 10: $433-442$

Submitted: October 18, 1999; Accepted: April 18, 2000

Proofs received from author(s): October 2, 2000 